\title{
The XIAP inhibitor embelin sensitises malignant rhabdoid tumour cells to TRAIL treatment via enhanced activation of the extrinsic apoptotic pathway
}

\author{
RACHEL COYLE $^{1}$, KAREN SLATTERY ${ }^{1}$, LEANNE ENNIS ${ }^{1}$, \\ MAUREEN J. O'SULLIVAN ${ }^{2}$ and DANIELA M. ZISTERER ${ }^{1}$ \\ ${ }^{1}$ School of Biochemistry and Immunology, Trinity Biomedical Sciences Institute, Trinity College Dublin, Dublin 2; \\ ${ }^{2}$ The National Children's Research Centre, Our Lady's Children's Hospital, Dublin 12, Ireland
}

Received August 20, 2018; Accepted February 13, 2019

DOI: 10.3892/ijo.2019.4804

\begin{abstract}
Malignant rhabdoid tumour (MRT) is a rare, aggressive paediatric neoplasm, primarily diagnosed in those below the age of three. MRTs most commonly arise in the central nervous system and kidneys. A poor prognosis accompanies the MRT diagnosis, with a reported 2-year survival rate of $30 \%$. Thus, there is an urgent need for the development of new therapies for this malignancy. Members of the inhibitor of apoptosis protein (IAP) family have previously been reported to be overexpressed in various cancers. As such, small molecule inhibitors of these family members have entered clinical trials. However, the role of IAPs in MRT has not been examined yet. The present study is the first report of the expression of a range of IAPs, including X-linked inhibitor of apoptosis (XIAP), cellular inhibitor of apoptosis protein 1 (cIAP1), cellular inhibitor of apoptosis protein 2 (cIAP2), livin and survivin in MRT cell lines. Furthermore, the results demonstrated the ability of the XIAP inhibitor, embelin, to sensitise MRT cell lines to TNF-related apoptosis-inducing ligand (TRAIL) treatment. The enhanced cell death detected upon cotreatment was dependent on caspase- 8 and co-occurred with caspase- 8 and caspase- 3 cleavage, suggesting engagement of the extrinsic apoptotic pathway. Sensitisation to TRAIL was accompanied by livin cleavage, alongside downregulation of survivin and the caspase-8 inhibitor FLIP $_{\mathrm{L}}$. In addition, knockdown of XIAP using siRNA enhanced TRAIL-mediated cell death, suggesting that this process may in part mediate sensitisation. In conclusion, the present results suggested that IAP inhibition may present a novel avenue for the treatment of MRT.
\end{abstract}

Correspondence to: Dr Rachel Coyle, School of Biochemistry and Immunology, Trinity Biomedical Sciences Institute, Trinity College Dublin, 152-160 Pearse Street, Dublin 2, Ireland

E-mail: racoyle@tcd.ie

Key words: cell death, malignant rhabdoid tumour, cancer, TNF-related apoptosis-inducing ligand, embelin, synergism

\section{Introduction}

Malignant rhabdoid tumour (MRT) is an aggressive paediatric neoplasm, primarily diagnosed in children under three $(1,2)$. MRTs most frequently arise in the brain, where they are referred to as atypical/teratoid rhabdoid tumours (AT/RT), or the kidneys. Common to rhabdoid tumours is an inactivating mutation in the SWI/SNF related, matrix associated, actin dependent regulator of chromatin, subfamily b, member 1 (SMARCB1) gene, leading to loss of expression of SMARCB1, a component of the SWI/SNF chromatin remodelling complex $(3,4)$. Unlike most cancers, MRTs are genomically stable, with SMARCB1 being the only commonly mutated gene identified (5-7). Currently, there is no standardised treatment protocol for MRT. Case reports in the literature, and numerous clinical trials are testament to this, with treatment regimens differing between institutions and often dependent upon tumour location. Treatment primarily consists of surgical resection of the tumour followed by aggressive chemotherapy, and if appropriate radiation therapy. Unfortunately, MRT is highly refractory to therapy, with retrospective reviews placing the 2-year event-free survival rate at $\leq 35 \%(8,9)$. The most successful trial to date treated $20 \mathrm{AT} / \mathrm{RT}$ patients with surgical resection, intensive chemotherapy and radiation, resulting in a 2-year overall survival rate of $70 \%$ (10). However, the dangers of pursuing such an aggressive regimen in children was evident with several associated toxicities and one toxic death reported. Given the poor prognosis and lack of treatment options, there is an urgent need for new therapies for MRT.

TNF-related apoptosis-inducing ligand (TRAIL) is a proapoptotic cytokine expressed by many tissue types of immune cells. Unlike other members of the TNF superfamily, TRAIL exhibits selectivity towards cancer cells whilst sparing healthy cells (11). While chemotherapeutics and radiation therapy elicit apoptosis through the intrinsic or mitochondrial apoptotic pathway, TRAIL, activates the extrinsic apoptotic pathway (12). Binding of TRAIL to its cognate death receptors, death receptor 4 (DR4) or death receptor 5 (DR5), results in receptor oligomerisation and formation of a membrane associated death inducing signalling complex (DISC) consisting of the adaptor protein FAS-associated via death 
domain (FADD), caspases 8 and 10, and the caspase-8 analogue FLICE-inhibitory protein (FLIP). The primary result of DISC formation is caspase- 8 activation. Once active, caspase- 8 cleaves and activates caspases 3 and 7, thus inducing apoptosis. In addition, TRAIL can engage the intrinsic pathway, as caspase- 8 may cleave the pro-apoptotic Bcl-2 protein Bid into its truncated form tBid, which mediates mitochondrial outer membrane permeabilization (MOMP). MOMP results in cytochrome c release which in turn facilitates caspase- 9 activation thus potentiating apoptosis. MOMP and thus the intrinsic apoptotic pathway is regulated by the $\mathrm{Bcl}-2$ family, which consists of pro and antiapoptotic members alongside regulatory proteins (13). In MRT, the antiapoptotic Bcl-2 protein myeloid leukaemia cell differentiation protein 1 (Mcl-1) has been demonstrated to be overexpressed (14). Unfortunately, clinical trials with TRAIL have yielded disappointing outcomes, with drug resistance being a primary issue (15-19). One approach to combat this, is the combination of TRAIL treatment with inhibition of negative regulators of the apoptotic process, such as FLIP-long form $\left(\right.$ FLIP $\left._{\mathrm{L}}\right)$, anti-apoptotic members of the Bcl-2 family and the inhibitor of apoptosis (IAP) family.

Of the IAP family, X-linked inhibitor of apoptosis (XIAP), cellular inhibitor of apoptosis protein (cIAP) 1, cIAP2, livin and survivin have been implicated in cancer progression and apoptosis inhibition, with their overexpression demonstrated in various malignancies, including acute myeloid leukaemia, neuroblastoma, hepatocellular carcinoma and renal cell carcinoma (20-28). To date, their role in MRT has not been examined. XIAP is the best characterised of these proteins and the only IAP which has been demonstrated to inhibit caspase activity directly (29-34). Specifically, XIAP has been demonstrated to bind and inhibit caspases 3,7 and $9(35,36)$. Embelin, the active constituent of the Embelia ribes shrub, is a small molecule which has been found to inhibit XIAP (37). Its tumour suppressive abilities have been demonstrated in leukaemia, prostate, breast, gastric and brain glioma cell lines (38-44). Its chemotherapeutic and radiation sensitising capacity has also been demonstrated in various cancers $(45,46)$. Additionally, there are an increasing number of studies reporting that embelin can sensitise both cancer cell lines and xenograft models to TRAIL (47-54). To the best of our knowledge, there is only one published report on TRAIL treatment in MRT cell lines, which found 3 of 6 tested cell lines to be sensitive to TRAIL (55). However, no combination regimens were tested. Furthermore, there are currently no reports on the effects of embelin, either alone or in combination, in MRT.

The results reported in the present study demonstrated for the first time the expression of a range of IAPs in MRT cell lines. In addition, embelin was determined to act as a sensitising agent to TRAIL in otherwise resistant MRT cell lines. This enhanced apoptosis was mediated in part by XIAP inhibition. The current findings thus suggest potential novel therapeutic options for MRT.

\section{Materials and methods}

Cells and reagents. BT12 and BT16 cell lines are epithelial AT/RT cells isolated from a 2 month old female and a 2-year-old male, respectively. These cell lines were generously donated by Peter Houghton, St. Jude Children's Research Hospital
(Memphis, TN, USA). G401 cells (American Type Culture Collection, Manassas, VA, USA) are epithelial kidney MRT cells isolated from a 3 month old male. BT12 and BT16 cell lines were cultured in Gibco RPMI-1640 GlutaMAX (Biosciences, Dublin, Ireland). G401 cells were cultured in Gibco Dulbecco's modified Eagle's medium (DMEM) GlutaMAX (Biosciences). All media used was supplemented with $10 \%(\mathrm{v} / \mathrm{v})$ foetal bovine serum (FBS; Biosciences), $100 \mathrm{U} / \mathrm{ml}$ penicillin and $100 \mu \mathrm{g} / \mathrm{ml}$ streptomycin (Biosciences). Cultured cells were incubated at $37^{\circ} \mathrm{C}$ with $5 \% \mathrm{CO}_{2}$. Cells were screened for mycoplasma using PCR and were consistently found to be negative for infection. A $1 \mathrm{mg} / \mathrm{ml}$ stock of recombinant human TRAIL (Merck KGaA, Darmstadt, Germany) was prepared in sterile $\mathrm{dH}_{2} \mathrm{O}$ and stored at $-80^{\circ} \mathrm{C}$. Dilutions were prepared fresh on the day of treatment. A $10 \mathrm{mM}$ stock of embelin (Sigma-aldrich; Merck KGaA) was prepared in ethanol and stored at $-20^{\circ} \mathrm{C}$. Stocks $(50 \mathrm{mM})$ of both the general caspase inhibitor (ZVAD-FMK; Calbiochem; Merck KGaA) and caspase-8 Inhibitor II [Z-IE(OMe) TD(OMe)-FMK; Calbiochem; Merck KGaA] were prepared in DMSO and ethanol respectively. Dilutions of both inhibitors were prepared fresh on the day of treatments in sterile $\mathrm{dH}_{2} \mathrm{O}$.

Cell viability assay. BT12, BT16 and G401 cell lines (200 $\mu \mathrm{l})$ were seeded at densities of $10 \times 10^{3}, 10 \times 10^{3}$ and $5 \times 10^{3}$ cells/well, respectively, in 96-well plates. Cells were left overnight to adhere and then treated with a range of concentrations of TRAIL or embelin for $72 \mathrm{~h}$. Viability was assessed via the alamar blue assay. Briefly, $20 \mu \mathrm{l}$ of AlamarBlue (Invitrogen; Thermo Fisher Scientific, Inc. Waltham, MA, USA) was added to each well. The plate was incubated in the dark at $37^{\circ} \mathrm{C}$ for $5 \mathrm{~h}$. Fluorescence was measured on a SpectraMax plate reader at an excitation wavelength of $544 \mathrm{~nm}$ and an emission wavelength of $590 \mathrm{~nm}$. All alamar blue assays were performed in triplicate.

Cell death analysis. For cell death analysis via propidium iodide (PI) staining, cells were collected by centrifugation and fixed in $70 \%$ ethanol overnight. The following day, $5 \mu \mathrm{l}$ of FBS and $1 \mathrm{ml}$ of PBS were added to each sample. Cells were collected by centrifugation and resuspended in BD FACSflow sheath fluid (BD Biosciences, San Jose, CA, USA) supplemented with $10 \mu \mathrm{g} / \mathrm{ml}$ of RNase A (Sigma-Aldrich; Merck KGaA) and $100 \mu \mathrm{g} / \mathrm{ml}$ of PI (Sigma-Aldrich; Merck KGaA). The samples were then incubated in the dark at $37^{\circ} \mathrm{C}$ for $30 \mathrm{~min}$. Analysis was performed with a BD Accuri C6 flow cytometer using BD Accuri C6 software (BD Biosciences). Samples were first gated on vehicle controls. A total of $1 \times 10^{5}$ cells from each sample were counted and results were visualised on histograms. PI was detected using a 585/40 bandpass filter. The sub G1/G0 population $(<2 \mathrm{n})$ was assigned as apoptotic cells.

For cell death analysis via Annexin V-fluorescein isothiocyanate (FITC) and PI staining, cells were collected by centrifugation and washed with $0.5 \mathrm{ml}$ Annexin $\mathrm{V}$ binding buffer (5 mM HEPES, $70 \mathrm{mM} \mathrm{NaCl}, 1.25 \mathrm{mM} \mathrm{CaCl}_{2} \mathrm{pH} 7.4$ ). The pellet from this wash was collected and stained with Annexin V-FITC (iQ Corporation, Groningen, Netherlands) for $30 \mathrm{~min}$ in the dark on ice. Cells were washed with $0.5 \mathrm{ml}$ of Annexin $\mathrm{V}$ binding buffer and collected by centrifugation. The pellet was resuspended in $500 \mu \mathrm{l}$ PI $(0.5 \mu \mathrm{g} / \mathrm{ml})$. The samples were then analysed immediately on BD Accuri C6 
flow cytometer using BD Accuri C6 software. Samples were first gated on vehicle controls. These gates were then analysed on a FITC-Annexin V (535 nm; FL1 channel using a 530/30 bandpass filter) vs PI (488 nm; FL2 using a 585/40 bandpass filter) dot plot.

Gel electrophoresis and western blot analysis. For whole cell lysates, cell pellets were resuspended in ice-cold RIPA buffer (Sigma-Aldrich; Merck KGaA) supplemented with protease inhibitor cocktail II and III (Sigma-Aldrich; Merck KGaA) and complete ultra protease inhibitor (Roche Applied Science, Penzberg, Germany) and kept on ice for $30 \mathrm{~min}$. Lysates were centrifuged at $10,000 \mathrm{x}$ g for $10 \mathrm{~min}$ and the pellet was discarded. For the cytosolic lysates, the cell pellet was resuspended in $75 \mu 1$ subcellular fractionation buffer $(250 \mathrm{mM}$ sucrose, 20 mM HEPES, $10 \mathrm{mM} \mathrm{KCL}, 1.5 \mathrm{mM} \mathrm{MgCl}_{2}, 1 \mathrm{mM}$ EDTA, 1 mM EGTA, 1 mM DTT, protease inhibitor cocktail) and kept agitated at $4^{\circ} \mathrm{C}$ for $30 \mathrm{~min}$. The suspension was centrifuged at $720 \mathrm{x}$ g for $5 \mathrm{~min}$ and the resultant supernatant was centrifuged further at $10,000 \mathrm{x} \mathrm{g}$ for $10 \mathrm{~min}$. The final resultant supernatant was the cytosolic lysate. For all lysates, protein concentration was determined using the BCA assay (Pierce; Thermo Fisher Scientific, Inc.) and normalised. Cell lysates were boiled with Laemmli sample buffer supplemented with $50 \mu \mathrm{M}$ DTT for $10 \mathrm{~min}$ at $90^{\circ} \mathrm{C}$. Equal concentrations of denatured samples were separated using polyacrylamide gel electrophoresis and transferred to an immobilion-P PVDF membrane (Merck KGaA). The membrane was blocked for $1 \mathrm{~h}$ in $5 \%$ non-fat dried milk and then incubated overnight at $4^{\circ} \mathrm{C}$ with the relevant primary antibody. The following primary antibodies were purchased form Cell Signaling Technology, Inc., (Danvers, MA, USA): XIAP (1:2,500; cat no. 2045), cIAP1 (1:1,000; cat no. 7065), cIAP2 (1:1,000; cat no. 3130), livin (1:1,000; cat no. 5471), survivin (1:1,000; cat no. 2808), caspase-3 (1:1,000; cat no. 9662$)$, cleaved caspase-3 (1:1,000; cat no. 9664), caspase-8 (1:1,000; cat no. 9746), cleaved caspase-8 (1:1,000; cat no. 9496$)$, caspase-9 $(1: 1,000$; cat no. 9508) Bid (1:1,000; cat no. 2002) and Mcl-1 (1:1,000; cat no. 4572). The following primary antibodies were also used: second mitochondria-derived activator of caspases (SMAC; 1:1,000; cat no. 612246; BD Biosciences), FLIP ${ }_{L}$ (1:2,000; cat no. MABC148; Merck KGaA) GAPDH (1:10,000; cat no. CB1001; Calbiochem), and $\alpha$ tubulin (1:1,000; cat no. CP0; Calbiochem). The following day the membrane was washed three times for $10 \mathrm{~min}$ each with TBST, probed with the relevant anti-rabbit $(1: 2,500$; cat no. W402B; Promega Corporation, Madison, WI, U.S.A.) or anti-mouse $(1: 2,500$; cat no. W401B; Promega Corporation) horseradish peroxidase (HRP)-conjugated secondary antibody, and then washed again as aforementioned. The membrane was soaked in enhanced chemiluminescence detection reagent (Merck KGaA). The western blot results were visualised using the BioRad Gel Doc $^{\mathrm{TM}} \mathrm{XR}+$ System with Image Lab software (Bio-Rad Laboratories, Inc., Hercules, CA, USA).

XIAP knockdown using small interfering (si) RNA. On-targetplus human XIAP siRNA SMARTpool (GE Healthcare Dharmacon, Inc., Lafayette, CO, USA) consisted of four siRNA sequences targeting XIAP, as follows: GUAGAU AGAUGGCAAUAUG, GAACUGGGCAGGUUGUAGA,
GAAAGAGAUUAGUACUGAA and GGACUCUACUACA CAGGUA. The negative control On-targetplus non-targeting pool (GE Healthcare Dharmacon, Inc.) consisted of four non-targeting siRNA sequences: UGGUUUACAUGUCGAC UAA, UGGUUUACAUGUUGUGUGA, UGGUUUACAU GUUUUCUGA, and UGGUUUACAUGUUUUCCUA. BT12 cells were seeded at $10 \times 10^{4}$ cells $/ \mathrm{ml}$ in antibiotic-free media in a 6-well plate. The following day, XIAP siRNA or non-targeting siRNA was transfected into cells using Lipofectamine (Thermo Fisher Scientific, Inc.) at a final concentration of $25 \mathrm{nM}$, as per manufacturer's instructions. Cell death was assessed $48 \mathrm{~h}$ post-treatment by flow cytometric analysis of PI-stained cells and subsequent quantification of the sub G1/G0 peak, as described above. Western blot analysis confirmed XIAP knockdown at 0 and 48 h of TRAIL treatment.

Determination of synergism. TRAIL and embelin combination treatments were assessed for synergism based upon the apoptosis they elicited, both as single drugs and in combination with one another, as determined by flow cytometric analysis of PI-stained cells, as described above. The computer software program Compusyn (ComboSyn, Inc., New Jersey, U.S.A.) was used to study the interactions between the drugs. This program uses the Chou-Talalay method, based upon the median effect principle, to determine Combination Index (CI) values for each drug combination. CI values $<1,=1$ and $>1$ indicate synergistic, additive and antagonistic effects respectively.

Statistical analysis. GraphPad Prism 5 (GraphPad Software, Inc., La Jolla, CA, USA) was used for statistical analysis of experimental data. Results are displayed as the mean \pm standard error of the mean. To determine statistical significance, Student's t-test was used for comparisons between two groups, while a one-way analysis of variance followed by Tukey's multiple comparison test was performed for comparisons of more than two groups. $\mathrm{P}<0.05$ was considered to indicate a statistically significant difference.

\section{Results}

MRT cell lines express a range of antiapoptotic IAP proteins. BT12, BT16 and G401 cell lines were firstly analysed for expression of XIAP, cIAP1, cIAP2, livin and survivin via western blotting (Fig. 1A). Densitometric analysis was then performed (Fig. 1B-G). All three cell lines were demonstrated to express a range of IAPs, with XIAP, cIAP1 and survivin universally expressed. Low levels of cIAP2 were detected in BT12 cells only. Livin exists as two splice variants; livin $\alpha$ and livin $\beta$. Both splice variants were detected in BT12 and G401 cells, while neither was detected in the BT16 cell line.

TRAIL and embelin exhibit limited effects on the viability of MRT cells. Yoshida et al (55) have previously reported a decreased viability of MRT cell lines upon TRAIL treatment. Given this, and combined with the XIAP expression demonstrated in Fig. 1, the viability of BT12, BT16 and G401 cell lines was assessed following treatment with TRAIL or the XIAP inhibitor, embelin, for $72 \mathrm{~h}$ via the alamarBlue assay (Fig. 2A). Viability dropped to only 60, 71 and $89 \%$ for G401, BT12 and BT16 cells, respectively, at 1,000 ng/ml 

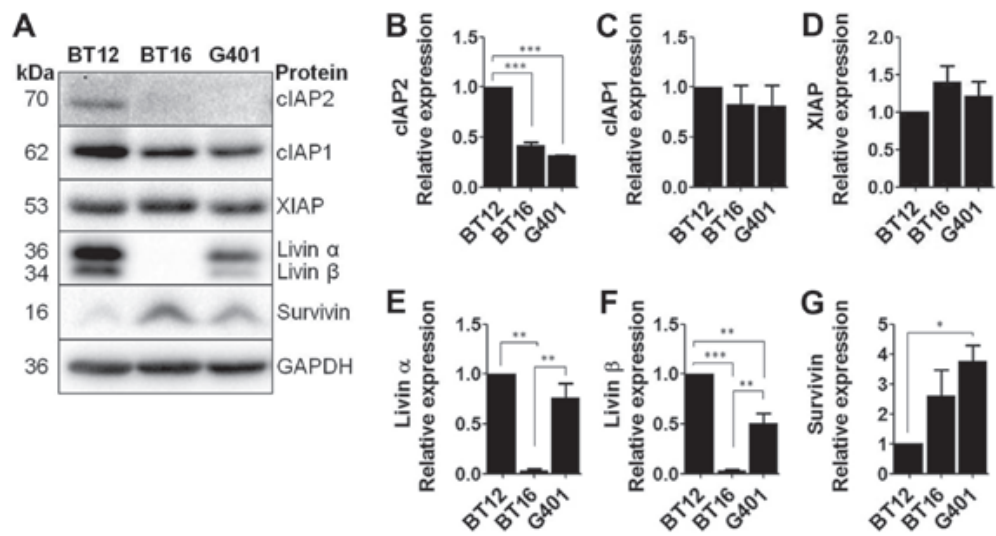

Figure 1. MRT cell lines express a range of IAP family members. (A) Expression levels of cIAP2, cIAP1, XIAP, Livin $\alpha$, Livin $\beta$ and survivin in malignant rhabdoid tumour cell lines, BT12, BT16 and G401, were detected by western blotting. GAPDH was used as a loading control. (B-G) Western blots were normalised to GAPDH and densitometric analysis was performed. Values are mean \pm standard error of the mean of at least three independent experiments. ${ }^{*} \mathrm{P}<0.05,{ }^{* *} \mathrm{P}<0.01$ and ${ }^{* * * *} \mathrm{P}<0.001$ with comparisons indicated by brackets. MRT, malignant rhabdoid tumour; IAP, inhibitor of apoptosis protein; cIAP, cellular inhibitor of apoptosis protein; XIAP, X-linked inhibitor of apoptosis.

TRAIL. Embelin reduced the viability of all three cell lines in a dose dependent manner. However, even at $50 \mu \mathrm{M}$ dose, the viability did not decrease below $33 \%$ for any cell line. BT12 and BT16 cells had similar $\mathrm{IC}_{50}$ values of 13.06 and $14.52 \mu \mathrm{M}$, respectively, with viability plateauing approximately 44 and $37 \%$, respectively. $\mathrm{The} \mathrm{IC}_{50}$ value for the $\mathrm{G} 401$ cell line was considerably higher at $47.14 \mu \mathrm{M}$.

Embelin synergistically enhances TRAIL-mediated cell death in MRT cell lines. Having shown the expression of XIAP in a range of MRT cell lines, and their resistance to TRAIL treatment, the present study next assessed if embelin could sensitise MRT cell lines to TRAIL. BT12, BT16 and G401 cell lines were treated with a range of concentrations of TRAIL, both alone and in combination with $10 \mu \mathrm{M}$ embelin, for 24,48 and $72 \mathrm{~h}$. This concentration of embelin is at the lowest end of the range (10-50 $\mu \mathrm{M})$ previously demonstrated to enhance susceptibility to TRAIL (47-54). It was selected for the present study, as lower doses are preferable in cancer therapeutics in order to minimise potential side effects. Cell death was assessed via PI staining of permeabilised cells and subsequent quantification of the sub G1/G0 peak. The computer program Compusyn was used to determine synergism. This program computes combination index $(\mathrm{CI})$ values for each drug combination. CI values $<1$, $=1$ and $>1$ indicate synergistic, additive and antagonistic effects respectively, with lower CI values indicating greater synergism. In BT12 cells, treatment with TRAIL or embelin alone did not cause significant cell death compared with vehicle, at any concentration tested. Combination treatment resulted in a dose and time-dependent increase in cell death, which was significant and synergistic at all concentrations and at several timepoints (Fig. 2B; Table I). Treatment with TRAIL at $50 \mathrm{ng} / \mathrm{ml}$ in combination with $10 \mu \mathrm{M}$ embelin was determined to give the greatest synergism with a CI value at 0.169 (Table I). Annexin V-PI staining, was then employed to confirm the increased cell death upon combination treatment with concurring results obtained (Fig. 2C). Similarly, in BT16 cells, embelin synergistically enhanced TRAIL-mediated cell death across a range of timepoints and concentrations, with $\mathrm{CI}$ values $<1$ reported for all concentrations tested at 48 and $72 \mathrm{~h}$
(Fig. 2B; Table I). In the G401 cell line, combination treatment did not result in significantly higher cell death compared with TRAIL treatment alone, at any concentration tested (Fig. 2B), possibly owing to differences between MRTs arising in the kidney and the brain.

Combination treatment induces apoptosis through the extrinsic apoptotic pathway. To determine the mode of cell death initiated upon combination treatment, BT12 cells were pretreated with an inhibitor of necroptosis, necrostatin 1 or the general caspase inhibitor, Z-VAD-FMK. Pretreatment with necrostatin 1 had no effect on cell death (Fig. 3A). By contrast, pretreatment with Z-VAD-FMK prevented cell death (Fig. 3B), indicating apoptosis was occurring. In the literature, TRAIL-induced cell death has mostly been attributed to activation of the extrinsic apoptotic pathway, resulting firstly in caspase- 8 activation, followed by downstream activation of caspase-3, caspase-7 and in certain cell types caspase-9 (12). Pretreatment of BT12 cells with a specific caspase- 8 inhibitor, Z-IETD-FMK, abrogated cell death (Fig. 3C), suggesting that the extrinsic apoptotic pathway was induced upon TRAIL and embelin treatment. Caspase inhibition was further confirmed via western blot analysis (Fig. 3D).

Embelin prevents the recovery of MRT cells from TRAIL treatment over time. BT12 and BT16 cells were treated with TRAIL and embelin, both alone and in combination, from 1 to $48 \mathrm{~h}$. In both cell lines, TRAIL treatment resulted in an initial burst of cell death from $4 \mathrm{~h}$ (Fig. 4A and B). However, the cells recovered from TRAIL treatment with cell death decreasing steadily from 16 to $48 \mathrm{~h}$ in BT12 cells (Fig. 4A), and from 4 to $48 \mathrm{~h}$ in BT16 cells (Fig. 4B). By contrast, cell death increased upon combination treatment in a time-dependent manner in both cell lines. This suggests that embelin prevented the recovery of MRT cell lines from TRAIL treatment over time. Given the aforementioned findings that TRAIL and embelin-induced cell death was dependent on caspase- 8 activation, the extrinsic apoptotic pathway was examined over a range of timepoints. Treatment with TRAIL alone resulted in a decrease in full length caspase- 8 and generation of active 
A
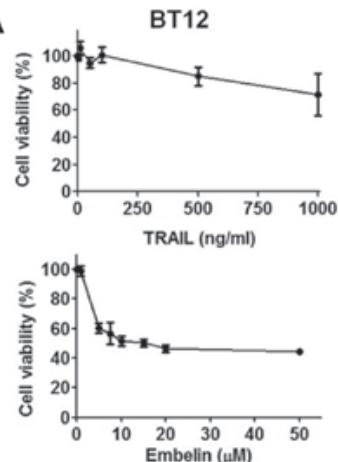

B
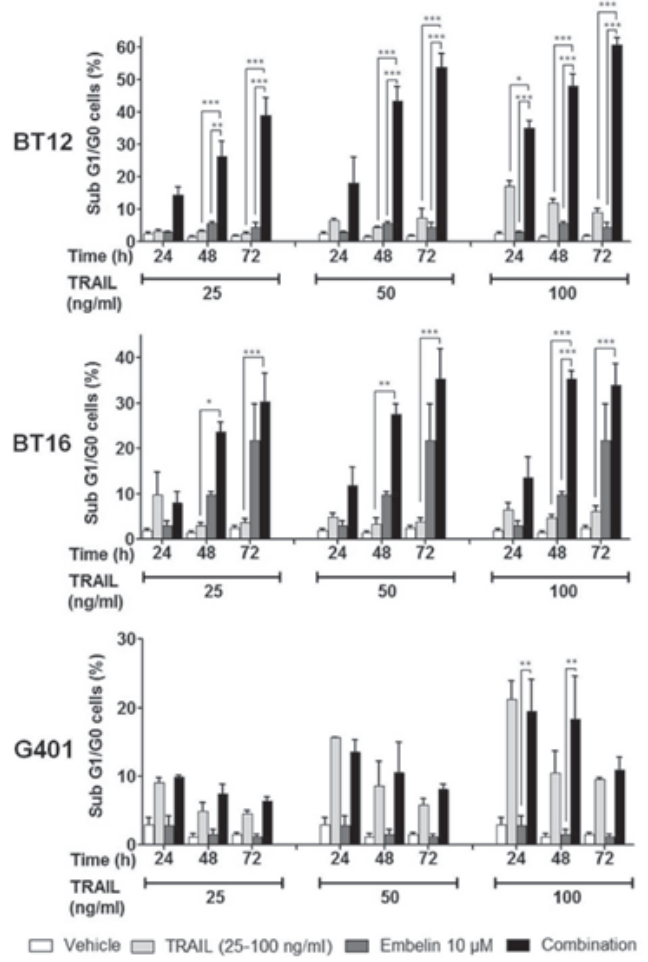
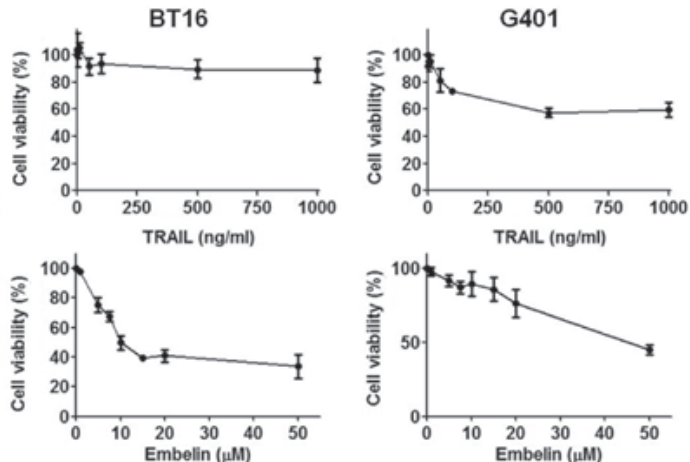

C
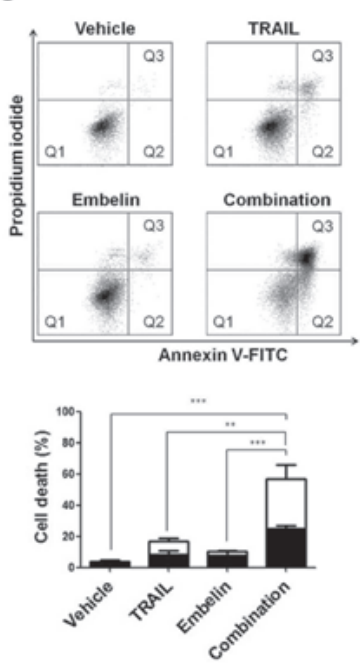

- Early apoptosis $\square$ Late apoptosis

Figure 2. Embelin enhances TRAIL-mediated cell death in MRT cell lines. (A) MRT cell lines, BT12, BT16 and G401, were treated with a range of concentrations of TRAIL or embelin. Viability was assessed $72 \mathrm{~h}$ post-treatment via the alamar blue assay. (B) MRT cell lines, BT12, BT16 and G401, were treated with a range of concentrations of TRAIL alone or in combination with $10 \mu \mathrm{M}$ embelin. Cell death was assessed at 24,48 and $72 \mathrm{~h}$ post-treatment via flow cytometric analysis of PI-stained cells and subsequent quantification of the sub G1/G0 peak. (C) BT12 cells were treated with 50 ng/ml TRAIL and $10 \mu \mathrm{M}$ embelin, both alone and in combination. Cell death was assessed 48 h post-treatment, via flow cytometric analysis of PI and Annexin-V FITC-stained cells. Cells which stained negative for PI and Annexin V are considered viable (Q1), cells which stained positive for Annexin V, but negative for PI were considered to be undergoing early apoptosis (Q2), and cells which stained positive for both PI and Annexin V were considered to be undergoing late apoptosis/necrosis $(\mathrm{Q} 3)$, as shown in the representative plots. Values are mean \pm standard error of the mean of at least three independent experiments. $\mathrm{P}<0.05$, ${ }^{* *} \mathrm{P}<0.01$ and ${ }^{*}{ }^{* * *}<0.001$ with comparisons indicated by brackets. TRAIL, TNF-related apoptosis-inducing ligand; MRT, malignant rhabdoid tumour; PI, propidium iodide; FITC, fluorescein isothiocyanate.

caspase-8 from $4 \mathrm{~h}$ (Fig. 4D). However, in agreement with the cell death results, caspase- 8 activation decreased from 4 to $48 \mathrm{~h}$. By contrast, combination treatment resulted in enhanced caspase- 8 cleavage compared with treatment with TRAIL alone from $4 \mathrm{~h}$ onwards (Fig. 4D). Bid, a target of caspase-8, was determined to be cleaved at $24 \mathrm{~h}$ in TRAIL-treated cells, with cleavage enhanced upon combination treatment (Fig. 4E). To determine if the generation of tBid was sufficient for MOMP, SMAC release into the cytosol was assessed from 1 to $24 \mathrm{~h}$. SMAC is a pro-apoptotic protein usually resident within the mitochondria. However, upon MOMP, SMAC is released into the cytosol where it is free to carry out its proapoptotic functions by binding and inhibiting XIAP $(33,56,57)$. Both TRAIL alone and combination treatment resulted in SMAC release, with levels slightly enhanced at $24 \mathrm{~h}$ in combination-treated cells (Fig. 4F). Despite SMAC release into the cytosol, indicative of MOMP, caspase-9 cleavage fragments, which would be formed upon caspase- 9 activation, were not detected using an antibody capable of detecting both full length and cleaved fragments (Fig. 4G). A further target of active caspase- 8 is caspase-3. Cleavage of caspase- 3 results in the generation of an inactive cleavage product of $19 \mathrm{kDa}$ and active cleavage products of 17 and $15 \mathrm{kDa}$. Treatment with TRAIL alone resulted in generation of both active and inactive cleavage fragments from $4 \mathrm{~h}$ onwards (Fig. $4 \mathrm{H}$ ). However, at later timepoints it was the inactive fragment which predominated. By contrast, combination treatment resulted in enhanced generation of 
Table I. Synergism between TRAIL and embelin in BT12 and BT16 cells.

\begin{tabular}{|c|c|c|c|c|c|}
\hline Cell line & Timepoint (h) & TRAIL (ng/ml) & $\mathrm{Fa}$ & CI value & Level of synergism \\
\hline \multirow[t]{9}{*}{ BT12 } & 24 & 25 & 0.144 & 0.35798 & +++ Synergism \\
\hline & & 50 & 0.18 & 0.50820 & +++ Synergism \\
\hline & & 100 & 0.352 & 0.470532 & +++ Synergism \\
\hline & 48 & 25 & 0.264 & 0.28718 & ++++ Strong Synergism \\
\hline & & 50 & 0.434 & 0.16938 & ++++ Strong Synergism \\
\hline & & 100 & 0.479 & 0.14939 & ++++ Strong Synergism \\
\hline & 72 & 25 & 0.39 & 0.43228 & +++ Synergism \\
\hline & & 50 & 0.538 & 0.33700 & +++ Synergism \\
\hline & & 100 & 0.607 & 0.31940 & +++ Synergism \\
\hline \multirow[t]{6}{*}{ BT16 } & 48 & 25 & 0.237 & 0.43825 & +++ Synergism \\
\hline & & 50 & 0.275 & 0.36781 & +++ Synergism \\
\hline & & 100 & 0.353 & 0.26640 & ++++ Strong Synergism \\
\hline & 72 & 25 & 0.3023 & 0.46910 & +++ Synergism \\
\hline & & 50 & 0.3527 & 0.35404 & +++ Synergism \\
\hline & & 100 & 0.3399 & 0.38200 & +++ Synergism \\
\hline
\end{tabular}

MRT cells, BT12 and BT16, were treated with a range of concentrations of TRAIL with and without $10 \mu \mathrm{M}$ embelin. After the relevant treatment time, cells were harvested, fixed and stained with propidium iodide. Cells were analysed by flow cytometry and apoptotic cells were determined by quantification of the sub G1/G0 peaks. The mean of at least three independent experiments, each of which was done in triplicate, was entered into Compusyn. CI Values $<1,=1$ and $>1$ indicate synergistic, additive and antagonistic effects, respectively. TRAIL, TNF-related apoptosis-inducing ligand; CI, combination index.

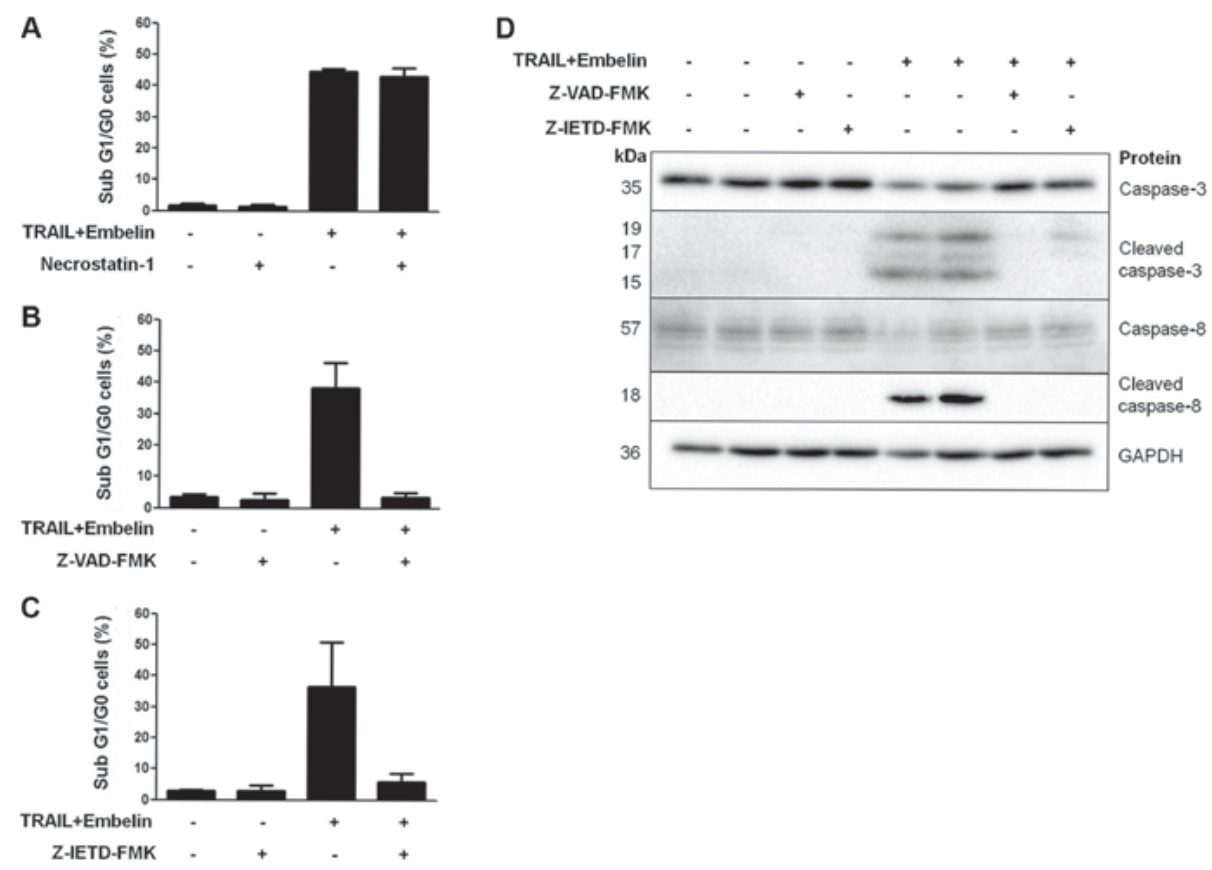

Figure 3. TRAIL and embelin induce cell death through the extrinsic apoptotic pathway in BT12 cells. (A) BT12 cells were pretreated with the receptor interacting threonine/serine kinase 1 inhibitor, necrostatin-1, (B) the general caspase inhibitor Z-VAD-FMK, or (C) the specific caspase-8 inhibitor, Z-IETD-FMK for $1 \mathrm{~h}$. Cells were then treated with $50 \mathrm{ng} / \mathrm{ml}$ TRAIL in combination with $10 \mu \mathrm{M}$ embelin for $24 \mathrm{~h}$ and cell death was assessed via flow cytometric analysis of propidium iodide-stained cells and subsequent quantification of the sub G1/G0 peak. Values are mean \pm standard error of of two independent experiments, except for panel A where values are representative of three independent experiments. (D) Caspase inhibition was confirmed via western blotting. TRAIL, TNF-related apoptosis-inducing ligand.

active cleavage fragments over time, with active caspase-3 levels being higher compared with the TRAIL alone-treated cells from $4 \mathrm{~h}$ onwards (Fig. $4 \mathrm{H}$ ). Caspase-3 activation was also assessed in BT16 cells at 24 and $48 \mathrm{~h}$. As per the BT12 cells, combination treatment resulted in enhanced generation of active caspase-3 over time (Fig. 4C). 

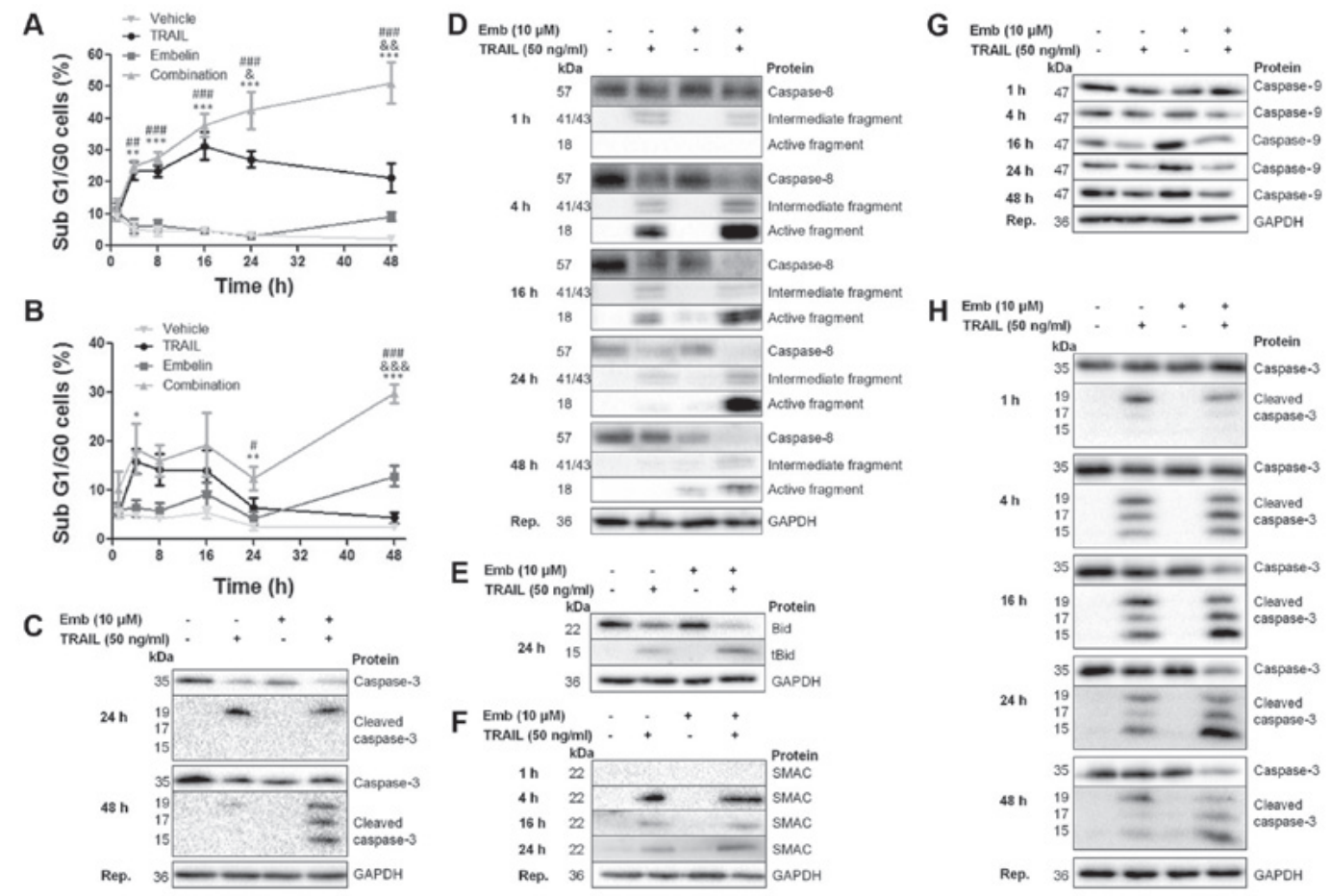

Figure 4. Embelin prevents the recovery of BT12 cells from TRAIL treatment with enhanced activation of the extrinsic apoptotic pathway over time. (A) BT12 and (B) BT16 cells were treated with $50 \mathrm{ng} / \mathrm{ml}$ TRAIL and $10 \mu \mathrm{M}$ embelin, both alone and in combination. Cell death was assessed at $1,4,8,16,24$ and $48 \mathrm{~h}$ post-treatment via flow cytometric analysis of propidium iodide-stained cells and subsequent quantification of the sub G1/G0 peak. Values are mean \pm standard error of the mean of at least three independent experiments. ${ }^{*} \mathrm{P}<0.05,{ }^{* *} \mathrm{P}<0.01$ and ${ }^{* * *} \mathrm{P}<0.001$ vs vehicle; ${ }^{\&} \mathrm{P}<0.05$, ${ }^{\& \&} \mathrm{P}<0.01$ and ${ }^{\& \& \&} \mathrm{P}<0.001 \mathrm{vs}$. TRAIL; and ${ }^{\#} \mathrm{P}<0.05,{ }^{\# \#} \mathrm{P}<0.01$ and ${ }^{\# \#} \mathrm{P}<0.001$ vs. embelin. (C) BT16 cells were treated with $50 \mathrm{ng} / \mathrm{mL}$ TRAIL and $10 \mu \mathrm{M}$ embelin, both alone and in combination. At 24 and $48 \mathrm{~h}$ post-treatment, expression of full length/cleaved caspase- 3 was examined. (D) BT12 cells were treated with $50 \mathrm{ng} / \mathrm{ml}$ TRAIL and $10 \mu \mathrm{M}$ embelin, both alone and in combination. At 1, 8, 16, 24 and 48 h post-treatment, expression of full length/cleaved caspase-8, (G) caspase-9 and (H) full length/cleaved caspase-3 was assessed via western blotting. (E) Bid cleavage was examined at $24 \mathrm{~h}$ and (F) SMAC release into the cytosol at $1,4,16$ and $24 \mathrm{~h}$. Results are representative of at least three independent experiments, except those for Bid and tBid which are representative of two independent experiments. TRAIL, TNF-related apoptosis-inducing ligand; Bid, BH3 interacting domain death agonist; tBid, truncated Bid; SMAC, second mitochondria-derived activator of caspases.

Combination treatment results in decreased expression of antiapoptotic proteins. BT12 cells were treated with TRAIL and embelin, either alone or in combination, from 1 to $48 \mathrm{~h}$ and protein expression was analysed via western blotting. The expression levels of proteins which were implicated in sensitising the cells to apoptosis in the BT12 cells were then assessed in BT16 cells at 24 and $48 \mathrm{~h}$. No differences in XIAP expression levels were observed following TRAIL or embelin treatment at any timepoint (Fig. 5A). Combination treatment resulted in slightly reduced expression at 24 and $48 \mathrm{~h}$. XIAP expression in BT16 cells was similar (Fig. 6A). cIAP1 expression levels in BT12 cells were unaffected by any treatment at any timepoint (Fig. 5B). cIAP2 levels in BT12 cells were examined at $48 \mathrm{~h}$ only, due to technical limitations with the cIAP2 antibody, and were found to be slightly decreased following embelin or combination treatment (Fig. 5C). As aforementioned, livin exists as two splice variants, both of which can be cleaved by caspase-3, with the cleaved fragments suggested to be proapoptotic. In line with the cleaved caspase- 3 data, treatment with TRAIL resulted in livin cleavage from $4 \mathrm{~h}$ in BT12 cells (Fig. 5D). However, by $48 \mathrm{~h}$ livin levels were comparable to vehicle, in accordance with the recovery of cells from treatment. By contrast, combination treatment resulted in increased livin cleavage compared with treatment with TRAIL alone from $4 \mathrm{~h}$, with cleavage increasing in a time-dependent manner
(Fig. 5D). In BT12 cells, survivin levels were increased upon TRAIL treatment from 24 h (Fig. 5E). By contrast, treatment with embelin either alone or in combination with TRAIL resulted in reduced survivin expression from $16 \mathrm{~h}$ (Fig. 5E). Survivin levels in BT16 cells at 24 and $48 \mathrm{~h}$ were also decreased upon embelin or combination treatment (Fig. 6B). Expression levels of FLIP ${ }_{L}$, an analog and inhibitor of caspase- 8 , were unaffected by TRAIL or embelin single treatment (Fig. 5F). However, combination treatment resulted in reduced FLIP $_{\mathrm{L}}$ expression from $16 \mathrm{~h}$. By contrast, in

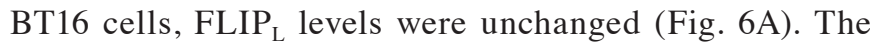
anti-apoptotic Bcl-2 family member Mcl-1, has previously been demonstrated to be overexpressed in MRT. Mcl-1 levels were unaffected by TRAIL or embelin single treatment, but were found to be decreased from $4 \mathrm{~h}$ in combination-treated cells (Fig. 5G). Similarly, in BT16 cells, embelin as a single agent or in combination with TRAIL resulted in reduced Mcl-1 expression at 24 and 48 h (Fig. 6B). Densitometric analysis of the proteins examined in Figs. 5 and 6 have been included as supplemental material (Figs. S1 and S2).

Knockdown of XIAP enhances TRAIL-mediated apoptosis. As described above, TRAIL and embelin co-treatment did not result in downregulation of XIAP until $24 \mathrm{~h}$ in MRT cell lines, despite enhanced caspase activity from $4 \mathrm{~h}$. However, the initial screening studies which identified embelin as an 

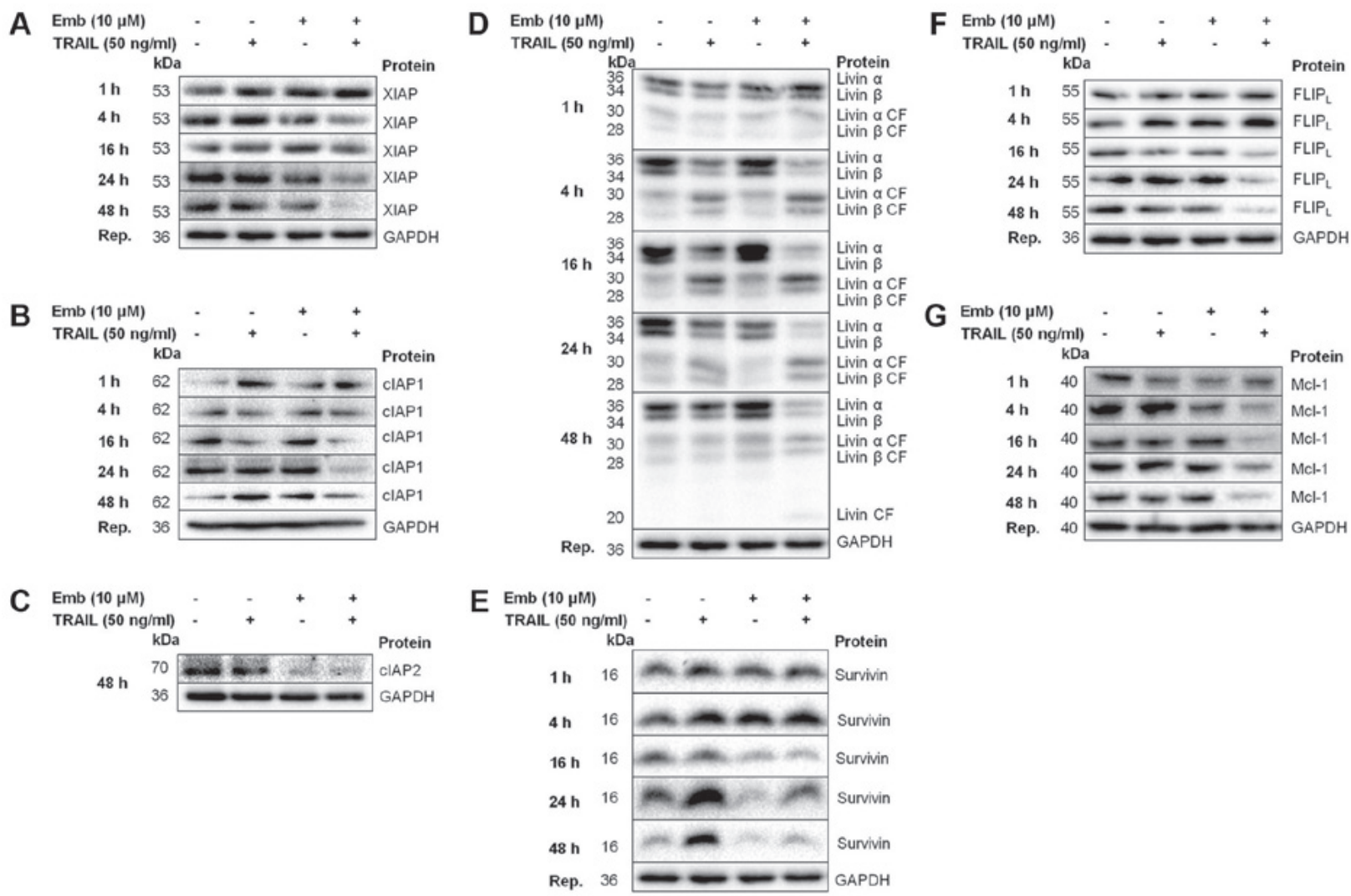

Figure 5. Decreased expression of antiapoptotic proteins, including early downregulation of survivin, $\mathrm{FLIP}_{\mathrm{L}}$ and Mcl-1 accompanies combination treatment in BT12 cells. BT12 cells were treated with $50 \mathrm{ng} / \mathrm{ml}$ TRAIL and $10 \mu \mathrm{M}$ embelin, both alone and in combination. At 1, 8, 16, 24 and $48 \mathrm{~h}$ post-treatment, expression of (A) XIAP, (B) cIAP1, (C) cIAP2 (examined only at 48 h), (D) livin, (E) survivin, (F) FLIP ${ }_{\mathrm{L}}$ and (G) Mcl-1 was assessed via western blotting. Results are representative of at least three independent experiments. FLIP $_{\mathrm{L}}$, FLICE-inhibitory protein long form; Mcl-1, myeloid leukaemia cell differentiation protein 1; TRAIL, TNF-related apoptosis-inducing ligand; XIAP, X-linked inhibitor of apoptosis; cIAP, cellular inhibitor of apoptosis protein.
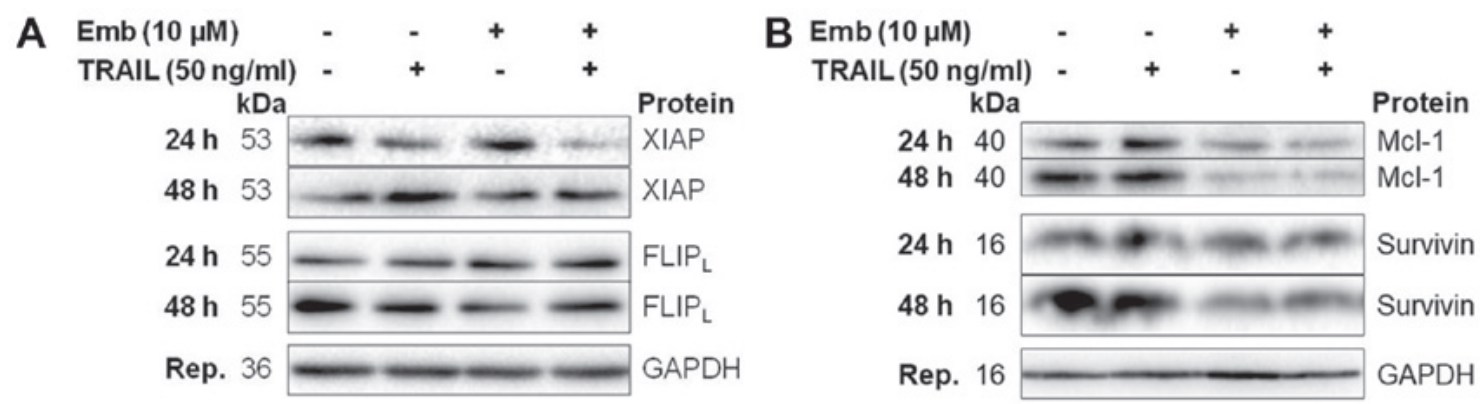

Figure 6. Embelin prevents the recovery of BT16 cells from TRAIL treatment with enhanced apoptosis induction, and decreased survivin and Mcl-1 expression over time. BT16 cells were treated with $50 \mathrm{ng} / \mathrm{ml}$ TRAIL and $10 \mu \mathrm{M}$ embelin, both alone and in combination. At 24 and $48 \mathrm{~h}$ post-treatment expression of (A) XIAP and FLIP $\mathrm{L}_{\mathrm{L}}$, and (B) survivin and Mcl-1 was assessed by western blotting. Results are representative of at least three independent experiments. TRAIL, TNF-related apoptosis-inducing ligand; Mcl-1, myeloid leukaemia cell differentiation protein 1; XIAP, X-linked inhibitor of apoptosis; FLIP ${ }_{\mathrm{L}}$ FLICE-inhibitory protein long form.

inhibitor of XIAP did not suggest degradation was necessary for inhibition (37). Given this and combined with previous reports of enhanced susceptibility to TRAIL upon XIAP knockdown, we next assessed if XIAP inhibition could account for the sensitisation of MRT cell lines to TRAIL upon embelin co-treatment. BT12 cells were treated with TRAIL in combination with XIAP siRNA or non-targeting siRNA and XIAP knockdown was confirmed via western blotting (Fig. 7A). While significant knockdown was achieved, low levels of XIAP expression were still detected (Fig. 7A). Despite this, cells treated with XIAP siRNA exhibited significantly enhanced TRAIL-mediated cell death, in contrast to cells treated with non-targeting siRNA (Fig. 7B). It should be noted that this enhanced cell death was not as pronounced as with the embelin cotreatment (Figs. 2B and 4A). While the incomplete knockdown of XIAP may account for this, it is likely that XIAP inhibition via embelin only partially mediates the enhanced cell death. A complex multifactorial mechanism of cell death is supported by the reduced survivin, FLIP and Mcl-1 expression demonstrated upon cotreatment. 
A

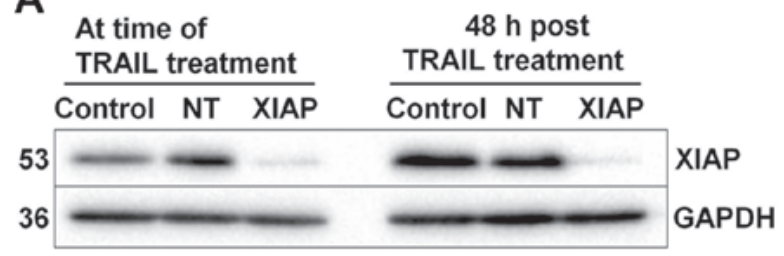

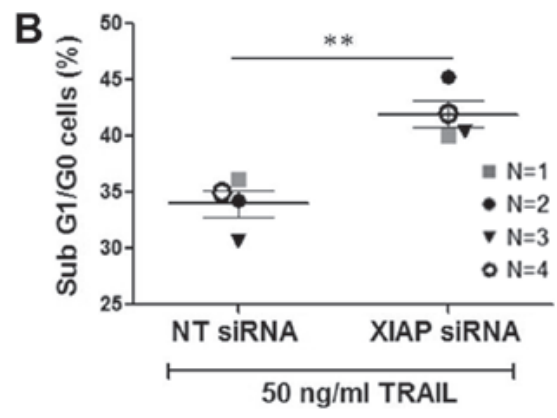

Figure 7. XIAP knockdown partially sensitises MRT cells to TRAIL treatment. BT12 cells were pretreated for $24 \mathrm{~h}$ with NT siRNA or XIAP siRNA. Cells were then treated with $50 \mathrm{ng} / \mathrm{ml}$ TRAIL for $48 \mathrm{~h}$. (A) XIAP knockdown was confirmed by western blotting. (B) Cell death as assessed in the control and knockdown cells by flow cytometric analysis of propidium iodide staining and subsequent quantification of the sub G1/G0 peak. Values are mean \pm standard error of the mean of four independent experiments. ${ }^{* *} \mathrm{P}<0.01$. XIAP, X-linked inhibitor of apoptosis; MRT, malignant rhabdoid tumour; TRAIL, TNF-related apoptosis-inducing ligand; si, small interfering; NT, non-targeting.

\section{Discussion}

MRT is a highly aggressive paediatric tumour, for which there is no standardised treatment. Its diagnosis carries with it a poor prognosis, and given its early age of onset, aggressive treatment is hindered by associated toxicities. As such, there is an urgent need for the development of safe effective therapies. TRAIL has demonstrated efficacy in many cancer cell lines and in in vivo models as a cancer therapeutic with limited side effects (11). However, clinical trials with TRAIL have yielded disappointing outcomes, with resistance being a primary issue (15-19). In recent years, reports have demonstrated enhanced susceptibility of cancer cells to TRAIL upon cotreatment with the XIAP inhibitor embelin (47-54). The present study, therefore, assessed the efficacy of TRAIL and embelin cotreatment in MRT cell lines.

The present study is the first to report the expression levels of antiapoptotic IAP family members in a panel of MRT cell lines. Further studies are underway into IAP expression in rhabdoid tumour patient samples (data not shown). XIAP, cIAP1, cIAP2, livin and survivin have frequently been reported to be overexpressed in a broad range of tumour types, including acute myeloid leukaemia, renal cell carcinoma, neuroblastoma and hepatocellular carcinoma (20-28). To this end, SMAC mimetics, inhibitors of XIAP, cIAP1 and cIAP2, have been developed, with several of them currently in clinical trials. The paediatric preclinical testing program (PPTP) has previously assessed treatment with the SMAC mimetic L6161 in a panel of cancer cells, including two MRT cell lines (BT12 and CHLA-266 cells), with $\mathrm{IC}_{50}$ values $>10 \mu \mathrm{M}$ obtained for both (58). Despite the lack of response to LCL161 as a single agent in MRT reported by the PPTP, it would be interesting to evaluate its effects in combination with other cancer therapeutics, considering previous reports on its sensitising ability (59-62). In addition, YM155 is an agent which suppresses survivin gene promotion and is currently in clinical trials as a possible chemotherapeutic sensitising agent $(63,64)$. Given the demonstrated IAP expression reported in the present study, there is a rationale for the preclinical evaluation of a broad range of IAP targeting agents, such as SMAC mimetics, YM155 and the XIAP inhibitor embelin in MRT, both alone and in combination with various cancer therapeutics.
The current study examined the efficacy of embelin as a single agent in a panel of MRT cell lines. Embelin was found to elicit a partial decrease in viability at concentrations up to $50 \mu \mathrm{M}$ with $\mathrm{IC}_{50}$ values of $13.06,14.55$ and $47.14 \mu \mathrm{M}$ obtained for BT12, BT16 and G401 cells, respectively, upon $72 \mathrm{~h}$ treatment. While this is the first report on embelin treatment in MRT cell lines, its anticancer effects have previously been demonstrated in numerous other malignancies. $\mathrm{IC}_{50}$ values of $65,28,56$ and $60 \mu \mathrm{M}$ have been reported for HCT-116 (colon carcinoma), MCF-7 (breast cancer), MIAPaCa-2 (pancreas ductal carcinoma) and PC-3 (prostate cancer) cells, respectively, upon $48 \mathrm{~h}$ treatment (65). $\mathrm{IC}_{50}$ values $<6 \mu \mathrm{M}$ upon $72 \mathrm{~h}$ treatment have been reported in MCF-7 and MDA-MB-231 breast cancer cells (40). This places MRT within the mid-range of response to embelin as a single agent. However, the modest decrease in viability of MRT cells in response to embelin suggests that its clinical potential may lie in its use as a combinatorial rather than a single agent.

To date, the only report on the treatment of MRT with TRAIL was by Yoshida et al (55), which reported sensitivity in 3 out of 6 tested cell lines upon $18 \mathrm{~h}$ treatment. The present study has reported on a further 3 cell lines, with resistance detected in all 3 upon 72 h treatment. Notably, when tested between 1 and $48 \mathrm{~h}$, MRT cells initially responded to TRAIL treatment, but recovery was observed after $16 \mathrm{~h}$. This was confirmed by cell death and caspase analysis across a broad range of timepoints. The reasons for this recovery are not entirely obvious. It is possible that the surviving population increased proliferation upon TRAIL treatment mediating recovery. In support of this, previous reports have demonstrated nuclear factor $(\mathrm{NF})-\kappa \mathrm{B}$ and extracellular signal-regulated kinase (ERK) activation upon TRAIL stimulation (66-70). However, engagement of these pathways was not detected at a range of early and later timepoints in the present study (data not shown). Additionally, it is also possible that the cells became resistant to TRAIL over time. In line with this, studies by Flusberg et al (71) demonstrated that MCF10A and HCT116 cancer cells treated with TRAIL developed reversible resistance (71). While their surviving cells exhibited enhanced $N F-\kappa B$ signalling, this was found to be dispensable for resistance. The experimental design of the current study was clearly different to that described by Flusberg et al, which investigated exclusively the development of resistance in a survivor population. Yet, both 
suggest that cancer cells can develop resistance to TRAIL treatment independently of enhanced proliferative signalling.

Of note, the recovery of cells from TRAIL was inhibited by embelin co-treatment which resulted in synergistically enhanced cell death and caspase activity in BT12 and BT16 cells. The present results are supported by the literature where embelin has been reported to enhance TRAIL-mediated cell death in acute myeloid leukaemia, malignant glioma, pancreatic, inflammatory breast, and non-small cell lung cancer cell lines (47-54). Previous reports have differed in their proposed mechanism with changes in expression of anti-apoptotic proteins FLIP, XIAP, survivin and Bcl-2 family members, alongside altered regulation of the $\mathrm{NF}-\kappa \mathrm{B}$ and ERK pathways among the factors implicated. The mechanism may thus be concentration or cell type-specific. In MRT, at the doses used, enhanced cell death was accompanied by reduced expression of Mcl-1 from $4 \mathrm{~h}$ and reduced FLIP $_{\mathrm{L}}$ and survivin levels from $16 \mathrm{~h}$. No changes in XIAP expression were noted until relatively late timepoints, by which time caspase-3 activity was already enhanced. While this may suggest that the enhanced cell death observed did not rely upon embelin-mediated XIAP inhibition, it should be noted that the original screening studies which identified embelin as an inhibitor of XIAP did not suggest protein degradation to be necessary for inhibition (37). In the present study, XIAP knockdown, via siRNA, significantly enhanced TRAIL-mediated cell death. This was further supported by analysis of the cleaved caspase- 3 fragments, with the inactive fragment predominating in TRAIL-treated cells in contrast to further processing evident upon combination treatment. This is in line with results previously reported, where enhanced SMAC release resulted in increased XIAP inhibition and completed caspase-3 processing $(72,73)$. In addition, livin cleavage, likely mediated by caspase-3 was observed in correlation with increased caspase activity. Livin has been demonstrated to bind SMAC and is suggested to inhibit its XIAP inhibitory activity (74). Livin cleavage may thus facilitate enhanced SMAC inhibition of XIAP. Furthermore, the cleaved livin fragments generated have previously been demonstrated to be proapoptotic $(75,76)$. The present results suggest that the enhanced cell death observed upon embelin cotreatment is likely multifactorial, with reduced expression of the antiapoptotic proteins survivin, FLIP $_{\mathrm{L}}$ and Mcl-1 being combined with livin cleavage and XIAP inhibition, to most likely account for the synergism observed.

In conclusion, the current study has highlighted the antiapoptotic IAP family members as possible targets for the treatment of MRT and suggests that further preclinical evaluation of their inhibition is warranted. Furthermore, the present results suggest that the XIAP inhibitor embelin may be combined with TRAIL as a potential novel treatment strategy for MRT, an aggressive malignancy desperately in need of new therapeutic options.

\section{Acknowledgements}

Not applicable.

\section{Funding}

This study was supported by a Trinity College Dublin postgraduate Ussher fellowship (Grant no. 1826 9050332).

\section{Availability of data and materials}

The datasets used and/or analysed during the present study are available from the corresponding author on reasonable request.

\section{Author's contributions}

DMZ and MJO'S decided upon this line of study. Experiments were planned and designed by $\mathrm{DMZ}$ and RC. Experiments were executed by RC, with KS and LE performing initial optimisation experiments and repeating a number of experiments. RC prepared and labelled all figures, executed experiments for Figs. 2B-7 independently and performed repeats for Figs. 1 and $2 \mathrm{~A}$. KS performed a number of replicates for Fig. 2A and optimisation experiments for Fig. 2B. LE performed optimisation experiments for Figs. 1 and 2, and a number of replicates for Fig. 1A. The manuscript was written by RC and reviewed by DMZ and MJO'S. DMZ and MJO'S reviewed all figures for publication. All authors have read and approved the final manuscript.

\section{Ethics approval and consent to participate}

Not applicable.

\section{Patient consent for publication}

Not applicable.

\section{Competing interests}

The authors declare that they have no competing interests.

\section{References}

1. Brennan B, Stiller C and Bourdeaut F: Extracranial rhabdoid tumours: What we have learned so far and future directions. Lancet Oncol 14: e329-e336, 2013.

2. Geller JI, Roth JJ and Biegel JA: Biology and Treatment of Rhabdoid Tumor. Crit Rev Oncog 20: 199-216, 2015.

3. Biegel JA, Kalpana G, Knudsen ES, Packer RJ, Roberts CW, Thiele CJ, Weissman B and Smith M: The role of INI1 and the SWI/SNF complex in the development of rhabdoid tumors: Meeting summary from the workshop on childhood atypical teratoid/rhabdoid tumors. Cancer Res 62: 323-328, 2002.

4. Versteege I, Sévenet N, Lange J, Rousseau-Merck MF, Ambros P, Handgretinger R, Aurias A and Delattre O: Truncating mutations of hSNF5/INI1 in aggressive paediatric cancer. Nature 394: 203-206, 1998.

5. Hasselblatt M, Isken S, Linge A, Eikmeier K, Jeibmann A, Oyen F, Nagel I, Richter J, Bartelheim K, Kordes U, et al: High-resolution genomic analysis suggests the absence of recurrent genomic alterations other than SMARCB1 aberrations in atypical teratoid/rhabdoid tumors. Genes Chromosomes Cancer 52: 185-190, 2013.

6. Kieran MW, Roberts CW, Chi SN, Ligon KL, Rich BE, Macconaill LE, Garraway LA and Biegel JA: Absence of oncogenic canonical pathway mutations in aggressive pediatric rhabdoid tumors. Pediatric Blood Cancer 59: 1155-1157, 2012.

7. McKenna ES, Sansam CG, Cho YJ, Greulich H, Evans JA, Thom CS, Moreau LA, Biegel JA, Pomeroy SL, Roberts CW: Loss of the epigenetic tumor suppressor SNF5 leads to cancer without genomic instability. Mol Cell Biol 28: 6223-6233, 2008.

8. Lafay-Cousin L, Hawkins C, Carret AS, Johnston D, Zelcer S, Wilson B, Jabado N, Scheinemann K, Eisenstat D, Fryer C, et al: Central nervous system atypical teratoid rhabdoid tumours: The Canadian Paediatric Brain Tumour Consortium experience. Eur J Cancer 48: 353-359, 2012. 
9. Tekautz TM, Fuller CE, Blaney S, Fouladi M, Broniscer A Merchant TE, Krasin M, Dalton J, Hale G, Kun LE, et al: Atypical teratoid/rhabdoid tumors (ATRT): Improved survival in children 3 years of age and older with radiation therapy and high-dose alkylator-based chemotherapy. J Clin Oncol 23: 1491-1499, 2005.

10. Chi SN, Zimmerman MA, Yao X, Cohen KJ, Burger P, Biegel JA, Rorke-Adams LB, Fisher MJ, Janss A, Mazewski C, et al: Intensive multimodality treatment for children with newly diagnosed CNS atypical teratoid rhabdoid tumor. J Clin Oncol 27: 385-389, 2009.

11. Walczak H, Miller RE, Ariail K, Gliniak B, Griffith TS, Kubin M, Chin W, Jones J, Woodward A, Le T, et al: Tumoricidal activity of tumor necrosis factor-related apoptosis-inducing ligand in vivo. Nat Med 5: 157-163, 1999.

12. Walczak H: Death receptor-ligand systems in cancer, cell death, and inflammation. Cold Spring Harb Perspect Biol 5: a008698, 2013.

13. Czabotar PE, Lessene G, Strasser A and Adams JM: Control of apoptosis by the BCL-2 protein family: Implications for physiology and therapy. Nat Rev Mol Cell Biol 15: 49-63, 2014.

14. Ouchi K, Kuwahara Y, Iehara T, Miyachi M, Katsumi Y, Tsuchiya K, Konishi E, Yanagisawa A and Hosoi $\mathrm{H}$ : A NOXA/MCL-1 Imbalance Underlies Chemoresistance of Malignant Rhabdoid Tumor Cells. J Cell Physiol 231: 1932-1940, 2016.

15. Cai JH, Fu SM, Tu ZH, Deng LQ, Liang Z, Chen XP, Gong XJ and Wan LH: Survivin gene functions and relationships between expression and prognosis in patients with nasopharyngeal carcinoma. Asian Pac J Cancer Prev 16: 2341-2345, 2015.

16. Chen W, Qiu L, Hou J, Zhang X, Ke X, Wang Z, Zhou F, Yang S, Zhao Y, Leng Y, et al: Phase Ib Study of Recombinant Circularly Permuted TRAIL (CPT) in Relapsed or Refractory multiple Myeloma Patients. Blood 120: 1857, 2012.

17. Hotte SJ, Hirte HW, Chen EX, Siu LL, Le LH, Corey A, Iacobucci A, MacLean M, Lo L, Fox NL and Oza AM: A phase 1 study of mapatumumab (fully human monoclonal antibody to TRAIL-R1) in patients with advanced solid malignancies. Clin Cancer Res 14: 3450-3455, 2008

18. Pan Y, Xu R, Peach M, Huang CP, Branstetter D, Novotny W, Herbst RS, Eckhardt SG and Holland PM: Evaluation of pharmacodynamic biomarkers in a Phase 1a trial of dulanermin (rhApo2L/TRAIL) in patients with advanced tumours. Br J Cancer 105: 1830-1838, 2011

19. Soria JC, Márk Z, Zatloukal P, Szima B, Albert I, Juhász E, Pujol JL, Kozielski J, Baker N, Smethurst D, et al: Randomized phase II study of dulanermin in combination with paclitaxel, carboplatin, and bevacizumab in advanced non-small-cell lung cancer. J Clin Oncol 29: 4442-4451, 2011

20. Cho SB, Lee WS, Park YL, Kim N, Oh HH, Kim MY, Oak CY, Chung CY, Park HC, Kim JS, et al: Livin is associated with the invasive and oncogenic phenotypes of human hepatocellular carcinoma cells. Hepatol Res 45: 448-457, 2015.

21. Dasgupta A, Alvarado CS, Xu Z and Findley HW: Expression and functional role of inhibitor-of-apoptosis protein livin (BIRC7) in neuroblastoma. Biochem Biophys Res Commun 400: 53-59, 2010.

22. Kempkensteffen C, Hinz S, Christoph F, Köllermann J, Krause H, Schrader M, Schostak M, Miller K and Weikert S: Expression parameters of the inhibitors of apoptosis cIAP1 and cIAP2 in renal cell carcinomas and their prognostic relevance. Int J Cancer 120: 1081-1086, 2007.

23. Kim DK, Alvarado CS, Abramowsky CR, Gu L, Zhou M, Soe MM, Sullivan K, George B, Schemankewitz E and Findley HW: Expression of inhibitor-of-apoptosis protein (IAP) livin by neuroblastoma cells: correlation with prognostic factors and outcome. Pediatr Dev Pathol 8: 621-629, 2005.

24. Mizutani Y, Nakanishi H, Li YN, Matsubara H, Yamamoto K, Sato N, Shiraishi T, Nakamura T, Mikami K, Okihara K, et al: Overexpression of XIAP expression in renal cell carcinoma predicts a worse prognosis. Int J Oncol 30: 919-925, 2007.

25. Ramp U, Krieg T, Caliskan E, Mahotka C, Ebert T, Willers R, Gabbert HE and Gerharz CD: XIAP expression is an independent prognostic marker in clear-cell renal carcinomas. Hum Pathol 35: 1022-1028, 2004.

26. Shi YH, Ding WX, Zhou J, He JY, Xu Y, Gambotto AA, Rabinowich H, Fan J and Yin XM: Expression of X-linked inhibitor-of-apoptosis protein in hepatocellular carcinoma promotes metastasis and tumor recurrence. Hepatology 48: 497-507, 2008
27. Tamm I, Kornblau SM, Segall H, Krajewski S, Welsh K, Kitada S, Welsh K, Kitada S, Scudiero DA, Tudor G, Qui YH, Monks A, et al: Expression and prognostic significance of IAP-family genes in human cancers and myeloid leukemias. Clin Cancer Res 6: 1796-1803, 2000.

28. Tamm I, Richter S, Oltersdorf D, Creutzig U, Harbott J, Scholz F, Karawajew L, Ludwig WD and Wuchter C: High expression levels of $\mathrm{x}$-linked inhibitor of apoptosis protein and survivin correlate with poor overall survival in childhood de novo acute myeloid leukemia. Clin Cancer Res 10: 3737-3744, 2004

29. Huang Y, Park YC, Rich RL, Segal D, Myszka DG and Wu H: Structural basis of caspase inhibition by XIAP: Differential roles of the linker versus the BIR domain. Cell 104: 781-790, 2001.

30. Riedl SJ, Renatus M, Schwarzenbacher R, Zhou Q, Sun C, Fesik SW, Liddington RC and Salvesen GS: Structural basis for the inhibition of caspase-3 by XIAP. Cell 104: 791-800, 2001.

31. Scott FL, Denault JB, Riedl SJ, Shin H, Renatus M and Salvesen GS: XIAP inhibits caspase- 3 and -7 using two binding sites: evolutionarily conserved mechanism of IAPs. EMBO J 24: 645-655, 2005

32. Shiozaki EN, Chai J, Rigotti DJ, Riedl SJ, Li P, Srinivasula SM, AlnemriES, Fairman R and Shi Y: Mechanism of XIAP-mediated inhibition of caspase-9. Mol Cell 11: 519-527, 2003.

33. Srinivasula SM, Hegde R, Saleh A, Datta P, Shiozaki E, Chai J, Lee RA, Robbins PD, Fernandes-Alnemri T, Shi Y, et al: A conserved XIAP-interaction motif in caspase-9 and Smac/DIABLO regulates caspase activity and apoptosis. Nature 410: 112-116, 2001.

34. Suzuki Y, Nakabayashi Y, Nakata K, Reed JC and Takahashi R: $\mathrm{X}$-linked inhibitor of apoptosis protein (XIAP) inhibits caspase-3 and -7 in distinct modes. J Biol Chem 276: 27058-27063, 2001.

35. Deveraux QL, Roy N, Stennicke HR, Van Arsdale T, Zhou Q, Srinivasula SM, Srinivasula SM, Alnemri ES, Salvesen GS and Reed JC: IAPs block apoptotic events induced by caspase- 8 and cytochrome $\mathrm{c}$ by direct inhibition of distinct caspases. EMBO J 17: 2215-2223, 1998.

36. Deveraux QL, Takahashi R, Salvesen GS and Reed JC: X-linked IAP is a direct inhibitor of cell-death proteases. Nature 388 : 300-304, 1997.

37. Nikolovska-Coleska Z, Xu L, Hu Z, Tomita Y, Li P, Roller PP, Wang R, Fang X, Guo R, Zhang M, et al: Discovery of embelin as a cell-permeable, small-molecular weight inhibitor of XIAP through structure-based computational screening of a traditional herbal medicine three-dimensional structure database. J Med Chem 47: 2430-2440, 2004.

38. Hu R, Zhu K, Li Y, Yao K, Zhang R, Wang H, Yang W and Liu Z: Embelin induces apoptosis through down-regulation of XIAP in human leukemia cells. Med Oncol 28: 1584-1588, 2011.

39. Park N, Baek HS and Chun YJ: Embelin-Induced Apoptosis of Human Prostate Cancer Cells Is Mediated through Modulation of Akt and $\beta$-Catenin Signaling. PloS One 10: e0134760, 2015.

40. Shah P, Djisam R, Damulira H, Aganze A and Danquah M: Embelin inhibits proliferation, induces apoptosis and alters gene expression profiles in breast cancer cells. Pharmacol Rep 68: 638-644, 2016

41. Sumalatha KR, Abiramasundari G, Chetan GK, Divya T, Sudhandiran G and Sreepriya M: XIAP inhibitor and antiestrogen embelin abrogates metastasis and augments apoptosis in estrogen receptor positive human breast adenocarcinoma cell line MCF-7. Mol Biol Rep 41: 935-946, 2014.

42. Wang A, Zhang B, Zhang J, Wu W and Wu W: Embelin-induced brain glioma cell apoptosis and cell cycle arrest via the mitochondrial pathway. Oncol Rep 29: 2473-2478, 2013.

43. Wang DG, Sun YB, Ye F, Li W, Kharbuja P, Gao L, Zhang DY and Suo J: Anti-tumor activity of the X-linked inhibitor of apoptosis (XIAP) inhibitor embelin in gastric cancer cells. Mol Cell Biochem 386: 143-152, 2014.

44. Xu CL, Zheng B, Pei JH, Shen SJ and Wang JZ: Embelin induces apoptosis of human gastric carcinoma through inhibition of p38 MAPK and NF-kB signaling pathways. Mol Med Rep 14: 307-312, 2016.

45. Cheng YJ, Jiang HS, Hsu SL, Lin LC, Wu CL, Ghanta VK and Hsueh CM: XIAP-mediated protection of H460 lung cancer cells against cisplatin. Eur J Pharmacol 627: 75-84, 2010.

46. Dai Y, Desano J, Qu Y, Tang W, Meng Y, Lawrence TS and Xu L: Natural IAP inhibitor Embelin enhances therapeutic efficacy of ionizing radiation in prostate cancer. Am J Cancer Res 1: $128-143,2011$. 
47. Allensworth JL, Aird KM, Aldrich AJ, Batinic-Haberle I and Devi GR: XIAP inhibition and generation of reactive oxygen species enhances TRAIL sensitivity in inflammatory breast cancer cells. Mol Cancer Ther 11: 1518-1527, 2012.

48. Hu R, Yang Y, Liu Z, Jiang H, Zhu K, Li J and Xu W: The XIAP inhibitor Embelin enhances TRAIL-induced apoptosis in human leukemia cells by DR4 and DR5 upregulation. Tumour Biol 36: 769-777, 2015.

49. Jiang L, Hao JL, Jin ML, Zhang YG and Wei P: Effect of Embelin on TRAIL receptor $2 \mathrm{mAb}$-induced apoptosis of TRAIL-resistant A549 non-small cell lung cancer cells. Asian Pac J Cancer Prev 14: 6115-6120, 2013.

50. Mori T, Doi R, Kida A, Nagai K, Kami K, Ito D, Toyoda E, Kawaguchi Y and Uemoto S: Effect of the XIAP inhibitor Embelin on TRAIL-induced apoptosis of pancreatic cancer cells. J Surg Res 142: 281-286, 2007.

51. Qian H, Chen Y, Huang T, Liu T, Li X, Jiang G, Zhang W, Cheng S and Li P: Combined application of Embelin and tumor necrosis factor-related apoptosis-inducing ligand inhibits proliferation and invasion in osteosarcoma cells via caspase-induced apoptosis. Oncol Lett 15: 6931-6940, 2018.

52. Siegelin MD, Gaiser T and Siegelin Y: The XIAP inhibitor Embelin enhances TRAIL-mediated apoptosis in malignant glioma cells by down-regulation of the short isoform of FLIP. Neurochem Int 55: 423-430, 2009.

53. Yang S, Li SS, Yang XM, Yin DH and Wang L: Embelin prevents LMP1-induced TRAIL resistance via inhibition of XIAP in nasopharyngeal carcinoma cells. Oncol Lett 11: 4167-4176, 2016.

54. Yang T, Lan J, Huang Q, Chen X, Sun X, Liu X, Yang P, Jin T, Wang S and Mou X: Embelin sensitizes acute myeloid leukemia cells to TRAIL through XIAP inhibition and NF- $\mathrm{BB}$ inactivation. Cell Biochem Biophys 71: 291-297, 2015.

55. Yoshida S, Narita T, Koshida S, Ohta S and Takeuchi Y: TRAIL/Apo2L ligands induce apoptosis in malignant rhabdoid tumor cell lines. Pediatr Res 54: 709-717, 2003.

56. Du C, Fang M, Li Y, Li L and Wang X: Smac, a mitochondrial protein that promotes cytochrome c-dependent caspase activation by eliminating IAP inhibition. Cell 102: 33-42, 2000.

57. Ekert PG, Silke J, Hawkins CJ, Verhagen AM and Vaux DL: DIABLO promotes apoptosis by removing MIHA/XIAP from processed caspase 9. J Cell Biol 152: 483-490, 2001.

58. Houghton PJ, Kang MH, Reynolds CP, Morton CL, Kolb EA, Gorlick R, Keir ST, Carol H, Lock R, Maris JM, et al: Initial testing (stage 1) of LCL161, a SMAC mimetic, by the Pediatric Preclinical Testing Program. Pediatr Blood Cancer 58: 636-639, 2012.

59. Langemann D, Trochimiuk M, Appl B, Hundsdoerfer P, Reinshagen K and Eschenburg G: Sensitization of neuroblastoma for vincristine-induced apoptosis by Smac mimetic LCL161 is attended by $\mathrm{G} 2$ cell cycle arrest but is independent of NFKB, RIP1 and TNF- $\alpha$. Oncotarget 8: 87763-87772, 2017.

60. Najem S, Langemann D, Appl B, Trochimiuk M, Hundsdoerfer P, Reinshagen K and Eschenburg G: Smac mimetic LCL161 supports neuroblastoma chemotherapy in a drug class-dependent manner and synergistically interacts with ALK inhibitor TAE684 in cells with ALK mutation F1174L. Oncotarget 7: 72634-72653, 2016

61. Qin Q, Zuo Y, Yang X, Lu J, Zhan L, Xu L, Zhang C, Zhu H, Liu J, Liu Z, et al: Smac mimetic compound LCL161 sensitizes esophageal carcinoma cells to radiotherapy by inhibiting the expression of inhibitor of apoptosis protein. Tumour Biol 35: 2565-2574, 2014

62. Yang C, Wang H, Zhang B, Chen Y, Zhang Y, Sun X, Xiao G, Nan K, Ren H and Qin S: LCL161 increases paclitaxel-induced apoptosis by degrading cIAP1 and cIAP2 in NSCLC. J Exp Clin Cancer Res 35: 158, 2016
63. Clemens MR, Gladkov OA, Gartner E, Vladimirov V, Crown J, Steinberg J, Jie F and Keating A: Phase II, multicenter, open-label, randomized study of YM155 plus docetaxel as first-line treatment in patients with HER2-negative metastatic breast cancer. Breast Cancer Res Treat 149: 171-179, 2015.

64. Kelly RJ, Thomas A, Rajan A, Chun G, Lopez-Chavez A, Szabo E, Spencer S, Carter CA, Guha U, Khozin S, et al: A phase I/II study of sepantronium bromide (YM155, survivin suppressor) with paclitaxel and carboplatin in patients with advanced non-small-cell lung cancer. Ann Oncol 24: 2601-2606, 2013.

65. Singh B, Guru SK, Sharma R, Bharate SS, Khan IA, Bhushan S, Bharate SB and Vishwakarma RA: Synthesis and anti-proliferative activities of new derivatives of embelin. Bioorg Med Chem Lett 24: 4865-4870, 2014.

66. Hartwig T, Montinaro A, von Karstedt S, Sevko A, Surinova S, Chakravarthy A, Taraborrelli L, Draber P, Lafont E, Arce Vargas F, et al: The TRAIL-Induced Cancer Secretome Promotes a Tumor-Supportive Immune Microenvironment via CCR2. Mol Cell 65: 730-742.e5, 2017.

67. Henry CM and Martin SJ: Caspase- 8 Acts in a Non-enzymatic Role as a Scaffold for Assembly of a Pro-inflammatory 'FADDosome' Complex upon TRAIL Stimulation. Mol Cell 65: 715-729.e5, 2017.

68. Lafont E, Kantari-Mimoun C, Draber P, De Miguel D, Hartwig T, Reichert M, Kupka S, Shimizu Y, Taraborrelli L, Spit M, et al: The linear ubiquitin chain assembly complex regulates TRAIL-induced gene activation and cell death. EMBO J 36: 1147-1166, 2017.

69. Varfolomeev E, Maecker H, Sharp D, Lawrence D, Renz M, Vucic D and Ashkenazi A: Molecular determinants of kinase pathway activation by Apo2 ligand/tumor necrosis factor-related apoptosis-inducing ligand. J Biol Chem 280: 40599-40608, 2005.

70. von Karstedt S, Conti A, Nobis M, Montinaro A, Hartwig T, Lemke J, Legler K, Annewanter F, Campbell AD, Taraborrelli L, et al: Cancer cell-autonomous TRAIL-R signaling promotes KRAS-driven cancer progression, invasion, and metastasis. Cancer Cell 27: 561-573, 2015.

71. Flusberg DA, Roux J, Spencer SL and Sorger PK: Cells surviving fractional killing by TRAIL exhibit transient but sustainable resistance and inflammatory phenotypes. Mol Biol Cell 24: 2186-2200, 2013.

72. Hörnle M, Peters N, Thayaparasingham B, Vörsmann H, Kashkar $\mathrm{H}$ and Kulms D: Caspase-3 cleaves XIAP in a positive feedback loop to sensitize melanoma cells to TRAIL-induced apoptosis. Oncogene 30: 575-587, 2011.

73. Thayaparasingham B, Kunz A, Peters N and Kulms D: Sensitization of melanoma cells to TRAIL by UVB-induced and NF-kappaB-mediated downregulation of xIAP. Oncogene 28: 345-362, 2009

74. Ma L, Huang Y, Song Z, Feng S, Tian X, Du W, Qiu X, Heese K and Wu M: Livin promotes Smac/DIABLO degradation by ubiquitin-proteasome pathway. Cell Death Differ 13: 2079-2088, 2006.

75. Abd-Elrahman I, Hershko K, Neuman T, Nachmias B, Perlman R and Ben-Yehuda D: The inhibitor of apoptosis protein Livin (ML-IAP) plays a dual role in tumorigenicity. Cancer Res 69: 5475-5480, 2009.

76. Nachmias B, Ashhab Y, Bucholtz V, Drize O, Kadouri L, Lotem M, Peretz T, Mandelboim O and Ben-Yehuda D: Caspase-mediated cleavage converts Livin from an antiapoptotic to a proapoptotic factor: Implications for drug-resistant melanoma. Cancer Res 63: 6340-6349, 2003. 